\title{
Advances in the treatment of Raynaud's phenomenon
}

\author{
This article was published in the following Dove Press journal: \\ Vascular Health and Risk Management \\ 15 March 2010 \\ Number of times this article has been viewed
}

\author{
Terri L Levien \\ Drug Information Pharmacist \\ and Clinical Associate Professor, \\ College of Pharmacy, \\ Washington State University Spokane, \\ WA, USA
}

\begin{abstract}
Raynaud's phenomenon is a common condition characterized by vasospasm of the digital arteries and resulting cyanosis and redness. It often does not require pharmacologic management, but in some cases symptoms are severe and pharmacologic management is necessary. Calcium channel blockers are often used first-line, but in some patients are ineffective. Patients with severe symptoms or intolerance to available therapies have prompted exploration of alternative therapies, including endothelin antagonists, phosphodiesterase- 5 inhibitors, antioxidants, newer vasodilators, statins, and botulinum toxin. These newer therapies provide the focus for this review.
\end{abstract}

Keywords: Raynaud, iloprost, bosentan, phosphodiesterase-5 inhibitors

Raynaud's phenomenon (RP) is the transient digital ischemia that occurs upon exposure to cold temperature or emotional distress. It most commonly affects the fingers. RP occurs as a result of vasoconstriction of the digital arteries, precapillary arterioles, and cutaneous arteriovenous shunts. ${ }^{1}$ The initial white phase is marked by demarcated pale skin caused by vasoconstriction and cessation of regional blood flow. The second phase is a cyanotic phase as the residual blood in the finger desaturates. The attack usually ends with rapid reflow of blood to the digits, which results in a red appearance of the digits. The attack is often accompanied by pain or paresthesia due to sensory nerve ischemia. The prevalence of RP in the general population is approximately 3 to 5 percent. ${ }^{1,2}$

Primary RP is characterized by symmetric attacks; the absence of tissue necrosis, ulceration, or gangrene; the absence of a secondary cause; normal nailfold capillaries; a negative test for antinuclear antibody; and a normal erythrocyte sedimentation rate. Symptoms are generally mild, and age of onset is generally younger than 30 years. ${ }^{1,3}$

In contrast with primary RP, a secondary cause is suggested by age of onset greater than 30 years; episodes that are intense, painful, asymmetric, or associated with ischemic skin lesions; concomitant symptoms suggestive of a connective tissue disease; specific autoantibodies; and evidence of microvascular disease on microscopy of nail-fold capillaries. ${ }^{1,3}$ Up to $90 \%$ of patients with systemic sclerosis have secondary RP. ${ }^{4}$

Over 140 years since its first description, the pathophysiology of RP remains incompletely understood and is likely multifactorial. Vascular, intravascular, and neural abnormalities have all been implicated in the pathophysiology of RP. Among vascular
Correspondence:Terri L Levien Pharmacotherapy Department, WSU Spokane, PO Box 1495, Spokane, WA 992। $0-1495$, USA

$\mathrm{Tel}+\mathrm{I}(509) 358-766 \mathrm{I}$

Fax +I (509) 358-7744

Email levient@wsu.edu 
mediators, nitric oxide, endothelin-1, serotonin, thromboxane, and angiotensin have been suggested to play a role. Numerous neural mediators, including calcitonin gene-related peptide and neuropeptide $\mathrm{Y}$, and agents interacting with alpha-adrenoreceptors have also been implicated through impairment of vasodilation and increased vasoconstriction. In addition, platelet activation, fibrinolysis, and oxidative stress may contribute. ${ }^{2,3}$

Nonpharmacologic therapies include avoidance of cold temperatures, emotional stress, caffeine, and smoking, as well as avoidance of vasoconstrictive medications. ${ }^{3,5}$ Pharmacologic therapy has historically included dihydropyridine calcium channel blockers, alpha1-adrenergic blockers, angiotensin II receptor antagonists, topical nitroglycerin, and pentoxifylline. ${ }^{3,5}$ Patients with primary RP only occasionally require pharmacologic therapy; while such therapy is more common in patients with secondary RP. Despite therapy, some patients with severe attacks will develop intense pain, ulceration and ischemic skin lesions, and gangrene, and may ultimately require therapy with intravenous prostaglandins. Patients with severe symptoms or intolerance to available therapies have prompted exploration of alternative therapies, including endothelin antagonists, phosphodiesterase type 5 (PDE5) inhibitors, antioxidants, and newer vasodilators. No guidelines have been published for the therapy of RP, and many of the agents used in the treatment of RP are used off-label.

\section{Historical treatments and newer variations}

Calcium channel blockers remain the most widely used class of drugs in the management of RP. ${ }^{3}$ The dihydropyridine calcium channel blockers are most effective; nifedipine has been the most extensively studied. In a meta-analysis in primary RP, calcium channel blockers reduced frequency of attacks by 2.8 to 5 fewer attacks per week and severity by $33 \% .^{6}$ In another meta-analysis in RP secondary to systemic sclerosis, calcium channel blockers reduced RP attack frequency by 8.3 attacks over 2 weeks and severity by $35 \% .^{7}$ Calcium channel blockers typically used include nifedipine, nicardipine, felodipine, and amlodipine; once daily and sustained release dosage forms are preferred. ${ }^{3}$

A recent Cochrane review identified no other oral vasodilators with established efficacy in primary RP. ${ }^{8}$ Studies with angiotensin converting enzyme (ACE) inhibitors have not demonstrated a clear benefit. The angiotensin II receptor antagonist losartan reduced the severity and frequency of RP to a greater extent than nifedipine in primary RP in one small comparative study. ${ }^{9}$ The alpha1-adrenergic blocker prazosin was found to be modestly effective in the treatment of RP secondary to scleroderma in another Cochrane review. ${ }^{10}$ The vasodilator fasudil, a rho-kinase inhibitor, is also undergoing evaluation for the treatment of RP in patients with systemic scleroderma. ${ }^{11}$

Nitroglycerin ointments, sublingual tablets, and transdermal patches have also been used in the therapy of RP, demonstrating improvements in finger temperature and perfusion, but with a high incidence of side effects including headache and dizziness. Topical nitroglycerin reduces the severity and frequency of vasospastic episodes in primary and secondary RP. ${ }^{12-14}$

A new formulation of topical nitroglycerin is currently undergoing evaluation in clinical trials and has been submitted for approval in the United States. MQX-503 (MediQuest Therapeutics, Inc., Bothell, Washington, USA) consists of nitroglycerin in a microemulsion of approximately $50 \%$ lecithin-based organic phase and 50\% water phase. It is rapidly absorbed, and has a rapid onset of action. MQX-503 $0.5 \%$ and $1.25 \%$ were compared with placebo gel applied to fingers immediately prior to a cold challenge in 36 patients with primary or secondary Raynaud. Improvements in blood flow as assessed by laser Doppler were observed as early as 5 minutes after the cold challenge. The mean time to achieve baseline blood flow was shorter with MQX 1.25\% application; although there was no difference in time to achieve 50\% or $70 \%$ baseline skin temperature or in pain/numbness/tingling scores between the 3 groups. ${ }^{15}$

MQX-503 reduced the severity of RP, but not the duration or frequency, in a randomized, double-blind, placebocontrolled study enrolling 219 patients with primary or secondary RP who experienced at least 5 RP episodes in a 7 -day period during a placebo run-in phase. Over $90 \%$ of patients were female, with a mean age of 46 years. Over twothirds had secondary RP, primarily associated with systemic sclerosis. Patients received MQX-503 $0.9 \%$ or placebo with instructions to apply gel to the affected finger immediately before or up to 5 minutes after the onset of a RP event. The change in mean daily Raynaud's Condition Score (RCS) from baseline, the primary endpoint, was 0.48 with MQX-503 (14.3\%) compared with 0.04 (1.3\%) with placebo $(\mathrm{P}<0.04)$. The mean number and duration of RP events did not differ between treatments. In patients with systemic sclerosis, new digital ulcers developed with similar frequency in the two groups ( $9 \%$ with MQX-503 and 13\% with placebo; $P=0.51$ ). Adverse effects did not differ between groups; headache occurred in $23 \%$ of MQX-503 treated patients and $21 \%$ of placebo recipients. ${ }^{16}$ 
In a randomized, double-blind, crossover study enrolling 109 patients with moderate to severe primary or secondary RP (mean baseline RCS 3.9), treatment with MQX-503 $0.9 \%$ applied immediately before or within 5 minutes of onset of an attack was associated with a lower mean RCS than placebo (2.92 vs $3.17 ; P=0.009)$. An improvement in RCS of at least 2 points was achieved in $42 \%$ of patients with MQX-503 compared with $23 \%$ of patients with placebo. Mean measures of pain and numbness were also lower with MQX-503 compared with placebo. ${ }^{17}$

In combined data from three phase 3 studies of MQX-503 assessed for safety and tolerability, adverse events occurred with similar frequency with MQX-503 and vehicle placebo: headache $(17 \%$ and $15 \%)$, dizziness ( $6 \%$ and $5 \%$ ), and skin irritation $(2 \%$ and $2 \%){ }^{18}$

\section{Prostaglandin analogs}

For patients with an insufficient response to traditional vasodilators, prostaglandin analogs are sometimes given. Most of the literature involves the investigational use of iloprost, a stable analog of epoprostenol (prostaglandin $\mathrm{I}_{2}$ ), which has demonstrated variable activity in RP associated with systemic sclerosis. Iloprost is a potent vasodilator and inhibitor of platelet aggregation. In a 1998 Cochrane review, intravenous iloprost was reported to be effective in the treatment of RP secondary to scleroderma - decreasing the frequency and severity of attacks and preventing or healing digital ulcers. ${ }^{19}$ Results have not been consistent across all studies though. Intermittent iloprost infusions reduced the frequency and severity of RP attacks in patients with RP secondary to systemic sclerosis in a large randomized, placebo-controlled, double-blind study; however, there was no difference between treatments in digital ulcer healing. ${ }^{20}$ Iloprost was also associated with reduced frequency and severity of attacks in two small crossover studies. ${ }^{21,22}$ In another small study also enrolling patients with systemic sclerosis iloprost had no effect on RP severity or frequency, but was associated with improved ulcer healing. ${ }^{23}$ In another small study improvement in the frequency of RP attacks was observed, with no difference in duration or severity. ${ }^{24}$ High and low dose regimens were associated with a reduction in frequency, severity, and duration of RP attacks in a doubleblind study and in an open-label study. A reduction in digital ulcers was also reported in the latter. ${ }^{25,26}$ Other small studies compared intravenous iloprost with nifedipine in patients with RP associated with systemic sclerosis. Short term intravenous iloprost infusions produced a reduction in the number, duration, and severity of RP attacks comparable to oral nifedipine. ${ }^{27}$ Intermittent iloprost infusions improved skin scores and RP severity scores to a greater extent than oral nifedipine in a long-term comparative study. ${ }^{28}$ Table 1 summarizes the key studies with the intravenous iloprost. Other case reports, case series and observational studies have also described reduced RP attack severity, duration, and frequency, and improved ulcer healing with intermittent iloprost infusions. ${ }^{29-34}$ Iloprost was associated with a high incidence of adverse reactions during infusion, including headache, flushing, nausea, jaw pain, diarrhea, vomiting, injection site reactions, and myalgia; however, intermittent administration is possible. ${ }^{20,22,23,28}$

Other studies have also assessed an investigational oral iloprost in patients with RP secondary to systemic sclerosis, again with variable results. In one large study, oral iloprost $50 \mathrm{mcg}$ twice daily for 6 weeks was no more effective than placebo in reducing the frequency, duration, or severity of RP attacks. ${ }^{35}$ In a smaller study, oral iloprost $150 \mathrm{mcg}$ twice daily for 10 days was also no more effective than placebo in reducing RP attack duration or severity, was but preferred by patients. ${ }^{36}$ In another smaller study, oral iloprost $50 \mathrm{mcg}$ and $100 \mathrm{mcg}$ twice daily for 6 weeks was associated with reduced RP attack duration and severity, but no change in frequency. ${ }^{37}$ Reduced duration and severity of RP attacks was also reported in a series of 20 patients with primary or secondary RP treated with inhaled iloprost. ${ }^{38}$

Other prostaglandin analogs have also been assessed, without demonstrating consistent benefit. In a small openlabel assessment, daily infusion of alprostadil for six days was associated with a reduced frequency and severity of RP attacks in patients with systemic sclerosis ${ }^{39}$ however, in a double-blind, placebo-controlled study enrolling patients with primary RP or RP secondary to systemic sclerosis, IV alprostadil was no more effective than placebo. ${ }^{40} \mathrm{~A}$ doubleblind study revealed no differences between oral beraprost and placebo in the treatment of primary RP. ${ }^{41}$

\section{Endothelin receptor antagonists}

More recently studies have assessed the use of oral endothelin receptor antagonists as an alternative to prostaglandins in patients with severe RP not responding to other therapies. Endothelin- $\mathrm{A}\left(\mathrm{ET}_{\mathrm{A}}\right)$ receptors are found primarily in vascular smooth muscle cells and mediate vasoconstriction and cell proliferation. Endothelin- $\mathrm{B}\left(\mathrm{ET}_{\mathrm{B}}\right)$ receptors are found primarily on endothelial cells and mediate vasodilatation via nitric oxide. Bosentan acts as an antagonist primarily at $\mathrm{ET}_{\mathrm{A}}$ receptors, reducing vasoconstriction mediated by endogenous endothelin. In the United Kingdon and Ireland, bosentan is 
Table I Summary of intravenous iloprost clinical trials on Raynaud's phenomenon (RP)

\begin{tabular}{|c|c|c|c|c|}
\hline Patients & Study design & Active treatment & Outcomes & References \\
\hline $\begin{array}{l}\text { I } 3 \text { I patients } \\
\text { secondary RP }\end{array}$ & $\begin{array}{l}\text { Randomized } \\
\text { double-blind } \\
\text { placebo-controlled }\end{array}$ & $\begin{array}{l}\text { lloprost } 0.5-2 \mathrm{ng} / \mathrm{kg} / \mathrm{min} \text { IV infusion } \\
\text { over } 6 \text { hours on } 5 \text { consecutive days }\end{array}$ & $\begin{array}{l}\text { Frequency and severity reduced } \\
\text { Physician's rating of treatment effect improved } \\
\text { No difference in digital ulcer healing }\end{array}$ & 20 \\
\hline $\begin{array}{l}35 \text { patients } \\
\text { secondary RP }\end{array}$ & $\begin{array}{l}\text { Randomized } \\
\text { double-blind } \\
\text { placebo-controlled }\end{array}$ & $\begin{array}{l}\text { lloprost } 0.5-2 \mathrm{ng} / \mathrm{kg} / \mathrm{min} \text { over } 6 \mathrm{~h} \\
\text { on } 5 \text { consecutive days }\end{array}$ & $\begin{array}{l}\text { Complete digital ulcer healing } \\
\text { with iloprost } \\
\text { No difference in } \\
\text { frequency, duration, and severity }\end{array}$ & 23 \\
\hline $\begin{array}{l}\text { I } 3 \text { patients } \\
\text { secondary RP }\end{array}$ & $\begin{array}{l}\text { Randomized } \\
\text { double-blind } \\
\text { placebo-controlled } \\
\text { crossover }\end{array}$ & $\begin{array}{l}\text { lloprost } 0.5-2 \mathrm{ng} / \mathrm{kg} / \mathrm{min} \\
\text { over } 6 \mathrm{~h} \text { on } 5 \text { consecutive days }\end{array}$ & $\begin{array}{l}\text { Frequency reduced } \\
\text { No differences in duration } \\
\text { or severity }\end{array}$ & 24 \\
\hline $\begin{array}{l}29 \text { patients } \\
26 \text { secondary RP } \\
3 \text { primary RP }\end{array}$ & $\begin{array}{l}\text { Randomized } \\
\text { Double-blind } \\
\text { placebo-controlled } \\
\text { crossover }\end{array}$ & $\begin{array}{l}\text { lloprost } 0.5-2 \mathrm{ng} / \mathrm{kg} / \mathrm{min} \text { over } 6 \mathrm{~h} \\
\text { on } 3 \text { consecutive days }\end{array}$ & $\begin{array}{l}\text { Frequency and severity reduced } \\
\text { No difference in duration }\end{array}$ & 22 \\
\hline $\begin{array}{l}12 \text { patients } \\
\text { secondary RP }\end{array}$ & $\begin{array}{l}\text { Randomized } \\
\text { double-blind } \\
\text { placebo-controlled } \\
\text { crossover }\end{array}$ & $\begin{array}{l}\text { lloprost } \mathrm{I}-3 \mathrm{ng} / \mathrm{kg} / \mathrm{min} \text { over } \\
5 \text { hours on } 3 \text { consecutive days }\end{array}$ & $\begin{array}{l}\text { Frequency and severity } \\
\text { decreased with iloprost }\end{array}$ & 21 \\
\hline $\begin{array}{l}55 \text { patients } \\
\text { secondary RP }\end{array}$ & $\begin{array}{l}\text { Randomized } \\
\text { double-blind }\end{array}$ & $\begin{array}{l}\text { lloprost } 0.5 \mathrm{ng} / \mathrm{kg} / \mathrm{min} \text { or } \\
\text { Iloprost } 2 \mathrm{ng} / \mathrm{kg} / \mathrm{min} \text { over } 6 \mathrm{~h} \\
\text { on } 3 \text { consecutive days }\end{array}$ & $\begin{array}{l}\text { Frequency, severity, duration, and } \\
\text { digital skin lesions reduced to similar } \\
\text { extent with low dose and high dose }\end{array}$ & 25 \\
\hline $\begin{array}{l}46 \text { patients } \\
\text { secondary RP }\end{array}$ & $\begin{array}{l}\text { Randomized } \\
\text { single-blind }\end{array}$ & $\begin{array}{l}\text { lloprost } 2 \mathrm{ng} / \mathrm{kg} / \mathrm{min} \text { over } 8 \mathrm{~h} \text { on } \\
5 \text { consecutive days, then over } \\
8 \mathrm{hrs} \text { on I day every } 6 \text { weeks or } \\
\text { Nifedipine } 40 \mathrm{mg} / \text { day }\end{array}$ & $\begin{array}{l}\text { Skin scores reduced to greater extent } \\
\text { with iloprost than nifedipine } \\
\text { Severity scores reduced with iloprost, but } \\
\text { not with nifedipine }\end{array}$ & 28 \\
\hline $\begin{array}{l}23 \text { patients } \\
\text { secondary RP }\end{array}$ & $\begin{array}{l}\text { Randomized } \\
\text { double-blind } \\
\text { double-dummy }\end{array}$ & $\begin{array}{l}\text { lloprost } 0.5-2 \mathrm{ng} / \mathrm{kg} / \mathrm{min} \text { for } \\
8 \text { hours on } 3 \text { consecutive days, } \\
\text { repeated at week } 8 \text { or Nifedipine } 10 \mathrm{mg} \\
3 \text { times daily } \times 4 \text { weeks, then } 20 \mathrm{mg} 3 \text { times } \\
\text { daily } \times 12 \text { weeks }\end{array}$ & $\begin{array}{l}\text { Frequency, duration, severity, and } \\
\text { incidence of digital lesions reduced } \\
\text { to comparable extent with iloprost } \\
\text { and nifedipine }\end{array}$ & 27 \\
\hline
\end{tabular}

approved for the prevention of new digital ulcers in patients with systemic sclerosis and digital ulcers. Approval was based on the results of two studies (Table 2).

One randomized, double-blind, placebo-controlled study enrolling 122 patients with systemic sclerosis assessed the effects of bosentan in the prevention of digital ulcers. Patients received bosentan $62.5 \mathrm{mg}$ twice daily for 4 weeks, then $125 \mathrm{mg}$ twice daily for 12 weeks, or placebo for 16 weeks. Bosentan-treated patients had a $48 \%$ reduction in the mean number of new ulcers compared with those in the placebo group ( 1.4 vs 2.7 new ulcers; $P=0.0083$ ). A similar percentage of patients in both groups developed ulcers, and bosentan did not appear to delay development of the first digital ulcer. There was no difference between treatment groups in the healing of existing ulcers. ${ }^{42}$ In an open-label extension of this study, 88 patients ( 57 previously in the bosentan arm and 31 previously in the placebo arm) continued bosentan therapy for an additional 12 weeks. The mean number of new ulcers during follow-up was $0.7 .{ }^{43}$ In another similar study enrolling 188 patients with systemic sclerosis, bosentan $62.5 \mathrm{mg}$ twice daily for 4 weeks and then $125 \mathrm{mg}$ twice daily for 20 to 32 weeks was compared with placebo in the prevention and healing of digital ulcers. Total new ulcers during 24 weeks of follow-up were 1.9 on bosentan vs 2.7 on placebo $(P=0.035)$. Healing parameters, including time to healing of a selected cardinal ulcer, to to healing of all digital ulcers, and percent of patients with complete healing did not differ between treatment groups. ${ }^{44}$ Another study noted improvement in flow-mediated dilation with bosentan therapy in patients with systemic sclerosis, but did not include assessment of the frequency or severity of RP or digital ulcers. ${ }^{45}$

The use of bosentan in the treatment of digital ulcers in 26 patients with systemic sclerosis unresponsive to $\mathrm{CCB}$, ARBs, and sildenafil has also been described. Bosentan $62.5 \mathrm{mg}$ twice daily for the first month, then $125 \mathrm{mg}$ twice daily for an additional 35 weeks was administered. Healing 
Table 2 Summary of bosentan clinical trials on Raynaud's phenomenon (RP)

\begin{tabular}{|c|c|c|c|c|}
\hline Patients & Study design & Treatment & Outcomes & References \\
\hline $\begin{array}{l}22 \text { patients } \\
\text { secondary RP }\end{array}$ & $\begin{array}{l}\text { Randomized } \\
\text { double-blind } \\
\text { placebo-controlled }\end{array}$ & $\begin{array}{l}\text { Bosentan } 62.5 \mathrm{mg} \\
\text { twice daily } \times 4 \text { weeks, } \\
\text { then } 125 \mathrm{mg} \text { twice } \\
\text { daily } \times 12 \text { weeks }\end{array}$ & $\begin{array}{l}\text { Fewer new digital ulcers per patient with bosentan } \\
\text { (primary study outcome; mean of } 1.4 \text { new ulcers } \\
\text { per patient on bosentan vs } 2.7 \text { new ulcers per patient } \\
\text { on placebo [P }=0.0083] \text { ) } \\
\text { No difference in percentage } \\
\text { of patients with new digital ulcers, time to first ulcer, } \\
\text { ulcer healing, or functional improvement }\end{array}$ & 42 \\
\hline $\begin{array}{l}\text { I88 patients } \\
\text { secondary RP }\end{array}$ & $\begin{array}{l}\text { Randomized } \\
\text { double-blind } \\
\text { placebo-controlled }\end{array}$ & $\begin{array}{l}\text { Bosentan } 62.5 \mathrm{mg} \\
\text { twice daily } \times 4 \text { weeks, } \\
\text { then } 125 \mathrm{mg} \text { twice } \\
\text { daily } \times 20-32 \text { weeks }\end{array}$ & $\begin{array}{l}\text { Fewer new digital ulcers per patient with bosentan } \\
\text { (primary study outcome; mean of I.9 new ulcers } \\
\text { per patient on bosentan vs } 2.7 \text { new ulcers per patient } \\
\text { on placebo }[P=0.035] \text { ) } \\
\text { No difference in time to healing } \\
\text { of cardinal ulcer, time to healing of all digital ulcers, } \\
\text { and percent with complete healing }\end{array}$ & 44 \\
\hline
\end{tabular}

of ulcers was reported in $65 \%$ of patients after a median of 25 weeks (range 8 to 26 weeks). ${ }^{46}$ Reduction in ulcers, improved ulcer healing, and improvement in RP frequency and severity have also been reported in several case series and case reports including patients with systemic sclerosis. ${ }^{47-53}$ while another case series observed no improvement in RP activity, microvascular blood flow, systolic finger pressures, or disability scores. ${ }^{54}$

Bosentan toxicities include serious liver injury and major birth defects. In the United States bosentan is only approved by the Food and Drug Administration for use in the treatment of pulmonary arterial hypertension and is only available through a limited distribution system.

\section{Phosphodiesterase type $\mathbf{5}$ inhibitors}

Nitric oxide vasodilates and inhibits platelet activation by generating cyclic guanosine $5^{\prime}$-monophosphate. ${ }^{55}$ cGMP is hydrolyzed by phosphodiesterases, particularly the cGMPspecific phosphodiesterase-5 isoenzyme. Sildenafil, tadalafil, and vardenafil are selective inhibitors of cGMP-specific phosphodiesterase type 5 which increases cGMP, resulting in enhanced cGMP-dependent microvascular and macrovascular dilation. ${ }^{5,55}$ The use of PDE5 inhibitors is being explored in patients with RP because of their potential effects on the microvascular and macrovascular circulation.

Several small studies have assessed sildenafil, tadalafil, and vardenafil in the treatment of RP (study designs and key results are summarized in Table 3). These studies include a single-dose crossover study with sildenafil and alpha-tocopherol, ${ }^{56}$ a small study comparing tadalafil and pentoxifylline, ${ }^{57}$ two crossover studies comparing sildenafil and placebo, ${ }^{5,58}$ two crossover studies comparing tadalafil and placebo, ${ }^{59,60}$ and open-label uncontrolled studies of sildenafil, tadalafil, and vardenafil. ${ }^{61-64}$ Several of these studies have only been presented in meeting abstracts or as letters. ${ }^{56-62,64}$

A randomized, double-blind, crossover study compared the physiologic effects of single-dose sildenafil and alphatocopherol in 15 patients with RP. Following sildenafil, basal forearm blood flow and plasma cGMP were increased, and systolic and diastolic blood pressure were reduced. Alphatocopherol had no effect on any of these parameters. ${ }^{56}$ Clinical and blood flow effects of vardenafil have been assessed in 40 patients with primary or secondary RP in an open-label pilot study. Laser-Doppler measurements revealed improved digital blood flow in $70 \%$ of patients. Among those responding, peripheral blood flow was increased at room temperature and in a cold-exposure test at both 1 hour and 2 weeks after initiation of vardenafil. Symptomatic improvement was also observed, along with a reduction in the duration, frequency, and severity of attacks. ${ }^{63}$ Objective digital temperature responses following a mild cold challenge were observed in 3 of 5 patients treated with single dose of sildenafil in another open-label uncontrolled study. Subjective responses were also observed. ${ }^{64}$

Symptomatic improvement has been reported in several open-label studies. Primarily subjective endpoints were assessed in an open-label uncontrolled study of sildenafil in 10 female patients. Sildenafil $25 \mathrm{mg} 3$ times daily for 6 weeks was initiated following 5 days of intravenous iloprost therapy. Six of 10 patients demonstrated symptomatic improvement and five experienced ulcer healing. Among the six demonstrating clinical improvement, four showed an increase in finger skin temperature on thermography. ${ }^{61}$ Healing was also observed with sildenafil in an open-label study enrolling 
Table 3 Summary of phosphodiesterase type 5 inhibitor clinical trials on Raynaud's phenomenon (RP) with clinical endpoints

\begin{tabular}{|c|c|c|c|c|}
\hline Patients & Study design & Treatment & Outcomes & References \\
\hline \multicolumn{5}{|l|}{ Sildenafil } \\
\hline $\begin{array}{l}20 \text { patients } \\
16 \text { secondary RP } \\
2 \text { primary RP }\end{array}$ & $\begin{array}{l}\text { Randomized } \\
\text { double-blind crossover } \\
\text { placebo-controlled }\end{array}$ & $\begin{array}{l}\text { Sildenafil } 50 \mathrm{mg} \\
\text { twice daily } \times 4 \text { weeks }\end{array}$ & $\begin{array}{l}\text { Frequency and duration reduced } \\
\text { RCS improved }\end{array}$ & 5 \\
\hline $\begin{array}{l}20 \text { patients } \\
\text { primary RP }\end{array}$ & $\begin{array}{l}\text { Randomized } \\
\text { double-blind crossover } \\
\text { Placebo-controlled }\end{array}$ & $\begin{array}{l}\text { Sildenafil } 50 \mathrm{mg} \\
\text { twice daily } \times 2 \text { weeks }\end{array}$ & $\begin{array}{l}\text { No difference between } \\
\text { sildenafil and placebo in blood } \\
\text { flow, disability, pain, or RCS }\end{array}$ & 58 \\
\hline $\begin{array}{l}19 \text { patients } \\
\text { secondary RP }\end{array}$ & Open-label & $\begin{array}{l}\text { Sildenafil } 25 \text { to } 150 \mathrm{mg} / \text { day } \\
\text { for up to } 6 \text { months }\end{array}$ & $\begin{array}{l}\text { Mean number of ulcers reduced } \\
\text { VAS scores for RP, pain, and activity } \\
\text { were improved }\end{array}$ & 65,66 \\
\hline $\begin{array}{l}10 \text { patients } \\
\text { secondary RP }\end{array}$ & Open-label & $\begin{array}{l}\text { Sildenafil } 25 \mathrm{mg} 3 \text { time s } \\
\text { daily } \times 6 \text { weeks Initiated } \\
\text { following } 5 \text { days of } \\
\text { IV iloprost therapy }\end{array}$ & $\begin{array}{l}\text { Symptomatic improvement and ulcer } \\
\text { healing in approximately half }\end{array}$ & 61 \\
\hline \multicolumn{5}{|l|}{ Tadalafil } \\
\hline $\begin{array}{l}25 \text { patients } \\
\text { secondary RP }\end{array}$ & $\begin{array}{l}\text { Randomized } \\
\text { double-blind } \\
\text { cross-over }\end{array}$ & $\begin{array}{l}\text { Tadalafil } 20 \mathrm{mg} \text { or } \\
\text { placebo every other } \\
\text { day } \times 6 \text { weeks }\end{array}$ & $\begin{array}{l}\text { Frequency and duration reduced } \\
\text { Mean daily RCS improved } \\
\text { More ulcers healed during tadalafil } \\
\text { Fewer new finger tip ulcers } \\
\text { developed during tadalafil } \\
\text { Improvements with tadalafil on Patient Global } \\
\text { Assessment, Physician Global Assessment, and } \\
\text { impact on daily living on SSc HAQ }\end{array}$ & 59 \\
\hline $\begin{array}{l}39 \text { patients } \\
\text { secondary RP }\end{array}$ & $\begin{array}{l}\text { Randomized double-blind } \\
\text { placebo-controlled } \\
\text { cross-over }\end{array}$ & Tadalafil $20 \mathrm{mg}$ daily $\times 4$ weeks & $\begin{array}{l}\text { No significant differences from placebo in RCS } \\
\text { or RP frequency or duration }\end{array}$ & 60 \\
\hline $\begin{array}{l}\text { I } 4 \text { patients } \\
\text { secondary RP }\end{array}$ & Active-controlled & $\begin{array}{l}\text { Tadalafil } 20 \mathrm{mg} 2 \text { to } 3 \text { times per } \\
\text { week } \times 4 \text { weeks ( } 9 \text { patients) } \\
\text { or pentoxifylline } 600 \mathrm{mg} \text { twice } \\
\text { daily } \times 4 \text { weeks } \\
(5 \text { patients })\end{array}$ & $\begin{array}{l}\text { RCS improved with tadalafil compared } \\
\text { with pentoxifylline } \\
\text { Attack frequency and duration reduced with } \\
\text { tadalafil }\end{array}$ & 57 \\
\hline $\begin{array}{l}12 \text { patients } \\
\text { secondary RP }\end{array}$ & Open-label & $\begin{array}{l}\text { Tadalafil } 10 \text { or } 20 \mathrm{mg} \text { every } \\
\text { other day } \times 6 \text { weeks }\end{array}$ & Ulcer healing observed & 62 \\
\hline \multicolumn{5}{|l|}{ Vardenafil } \\
\hline $\begin{array}{l}40 \text { patients } \\
33 \text { secondary RP } \\
7 \text { primary RP }\end{array}$ & Open-label & $\begin{array}{l}\text { Vardenafil } 10 \mathrm{mg} \text { twice } \\
\text { daily } \times 2 \text { weeks }\end{array}$ & RCS reduced & 63 \\
\hline
\end{tabular}

Abbreviations and notes: RCS, Raynaud's Condition Score (patient assessment of the extent to which they felt handicapped by Raynaud attacks daily based on frequency, total daily duration, and severity of attacks using a 10-point scale; 0 points, subject felt not handicapped by Raynaud attacks; 10 points, subject felt extremely handicapped); HAQ, Health Assessment Questionnaire.

19 patients with systemic scleroderma, severe Raynaud, and digital ulcers. ${ }^{65,66}$ Another open-label study assessed tadalafil in 12 patients with secondary Raynaud and painful digital ulcers or finger tip necrosis at baseline. The mean time to ulcer healing was 5 weeks and the mean time to healing of fingertip necrosis was 8 weeks. ${ }^{62}$ In addition to open-label studies, several case reports and case series describing the use of PDE5 inhibitors in patients primarily with secondary RP have reported symptomatic improvement, ulcer healing, and objective improvements in blood flow. ${ }^{4,67-80}$
Tadalafil has been compared with pentoxifylline in the treatment of RP in a study enrolling 14 male patients with severe Raynaud associated with autoimmune diseases. RCS demonstrated greater improvement in the tadalafil treated patients. Attack frequency declined 59\% with tadalafil treatment compared with $36 \%$ reduction with pentoxifylline. Attack duration was also significantly reduced with tadalafil therapy compared with pentoxifylline. Both physician and patient assessments of RP were also improved after 4 weeks of therapy with tadalafil $(P<0.05$ compared with 2 weeks 
and $P<0.05$ vs controls). Results after 4 weeks of therapy were better than after 2 weeks of therapy. ${ }^{57}$

In a well-designed, randomized, double-blind, placebocontrolled, crossover study, sildenafil was assessed in the treatment of RP resistant to vasodilatory therapy. ${ }^{5}$ This assessment included 16 patients with secondary RP and 2 patients with primary RP. Inclusion criteria were the regular occurrence of painful Raynaud attacks and resistance to therapy with at least two conventional vasodilators. Therapy prior to study entry included calcium channel blockers in $94 \%$ of patients, nitroglycerin in $39 \%$, pentoxifylline in $28 \%$, ACE inhibitors in $22 \%$, intravenous prostaglandins in $17 \%$, and bosentan in $6 \%$. All vasodilatory agents were discontinued prior to study entry. Mean capillary flow velocity increased with sildenafil, but not placebo. In addition, attack frequency and duration were substantially reduced with sildenafil. In all six patients with chronic digital ulcerations, healing was observed during sildenafil treatment. In two patients, ulcerations completely cleared during sildenafil treatment, but reappeared or progressed upon discontinuation of sildenafil therapy.

Responses with tadalafil were observed in a randomized, double-blind, crossover study enrolling 25 patients with secondary Raynaud. The daily frequency, duration, and RCS scores were improved during tadalafil therapy. In addition all preexisting fingertip ulcers healed during the tadalafil phase, and fewer ulcers developed during the tadalafil phase than during the placebo phase..$^{59}$

In contrast with the benefits observed in the above studies and case reports, no benefit was observed in 20 patients with primary RP treated with sildenafil in a randomized, double-blind, crossover study. Patients received sildenafil $50 \mathrm{mg}$ twice daily or placebo for 2 weeks, followed by a 1-week washout period, and administration of the alternate agent for 2 weeks; this dosage regimen was identical to the regimen used in the preceding sildenafil study. No differences between sildenafil and placebo was observed in frequency and duration of Raynaud attacks, or measurements of blood supply to the digits upon exposure to cold. ${ }^{58}$

Another randomized, double-blind, placebo-controlled study of tadalafil in 39 patients with secondary Raynaud revealed no significant differences from placebo in RCS, or frequency and duration of RP. ${ }^{60}$ Similarly, tadalafil did not improve digital blood flow or attenuate cold-induced vasoconstriction in a population of patients mostly with primary Raynaud.$^{81}$

Limited adverse effect information was reported in these small studies and case reports. Adverse effects reported with sildenafil and vardenafil therapy in patients with RP have included headache, muscle pain, flushing, facial heat sensation, rhinorrhea, nausea, dyspepsia, dizziness, and visual abnormalities. ${ }^{5,56,68}$ These adverse effects are similar to those observed with PDE5 inhibitors in the treatment of erectile dysfunction.

\section{Serotonin receptor antagonists and serotonin reuptake inhibitors}

The role of serotonin in the pathophysiology and management of RP is not clearly established. Remission of RP symptoms has been described in a patient treated with fluoxetine; possibly as a result of depletion of platelet serotonin. ${ }^{82}$ Other case reports have described improvement with sertraline and escitalopram ${ }^{83,84} \mathrm{~A}$ crossover study has also compared fluoxetine with nifedipine in the treatment of 26 patients with primary and 27 patients with secondary RP. Patients received fluoxetine $20 \mathrm{mg}$ daily or nifedipine $40 \mathrm{mg}$ daily for 6 weeks, followed by a 2-week washout period and then therapy with the alternate agent. Attack frequency and severity were reduced with either therapy; however, the effect was significant only during the fluoxetine therapy ${ }^{85}$ Numerous other reports, however, have described exacerbation of RP symptoms following initiation of therapy with a serotonin reuptake inhibitors and serotonin partial agonists (fluoxetine, fluvoxamine, citalopram, reboxetine, tegaserod). ${ }^{86-90}$

Sarpogrelate is a selective serotonin 5HT2 receptor antagonist that is undergoing evaluation in the treatment of RP. In a small study enrolling 7 patients with systemic sclerosis, sarpogrelate $300 \mathrm{mg}$ once daily for 12 months was associated with a decreased frequency and duration of $\mathrm{RP}$, as well as the coldness, numbness and pain of RP. The effect appeared to be mediated by reduction in the plasma concentration of fibrinopeptide A (FPA), beta thromboglobulin (beta-TG), and platelet factor 4 (PF4), and prevention of platelet aggregation. ${ }^{91}$ Improvement in the frequency and duration of RP and symptoms of coldness and pain were also described in a Japanese report including 32 patients with secondary RP treated with sarpogrelate $300 \mathrm{mg}$ once daily for 8 weeks, and in a meeting abstract reporting on 12 patients with secondary RP treated with sarpogrelate $300 \mathrm{mg}$ once daily for 12 weeks. ${ }^{92,93}$

\section{Antioxidants}

$\mathrm{N}$-Acetylcysteine has also demonstrated activity in patients with RP secondary to systemic sclerosis. The use of $\mathrm{N}$-acetylcysteine in the treatment of RP has been described in an open-label pilot study enrolling 22 patients with RP secondary to systemic sclerosis. The study was conducted 
over 11 weeks during the winter. Patients received a continuous 5-day intravenous infusion of $\mathrm{N}$-acetylcysteine starting with a 2-hour loading dose of $150 \mathrm{mg} / \mathrm{kg}$ followed by a dose of $15 \mathrm{mg} / \mathrm{kg} /$ hour. The primary outcome measures were the frequency and severity of RP attacks, and the number of digital ulcers. Frequency and severity of RP attacks were both reduced. Frequency was reduced from 21.2 RP attacks per week at baseline to 10.7 attacks per week from days 5 to 19, 12.1 per week from days 20-33, and 14.1 per week from days 34 to 61 . Severity scores declined from 5.5 at baseline to 3.4 at days 5 to $19,2.9$ at days 20 to 33 , and 3.1 at days 34 to 61 . Digital ulcers were reduced at least $50 \%$ in $80 \%$ of patients at day 33 after the infusion, with 53\% demonstrating complete ulcer healing. In a cold challenge test assessed by photoelectric plethysmography, mean recovery time fell by approximately $70 \% .{ }^{94}$ In a subsequent assessment of the longterm use of $\mathrm{N}$-acetylcysteine in patients with RP secondary to systemic sclerosis, patients treated with an intravenous dose of $15 \mathrm{mg} / \mathrm{kg} /$ hour for 5 consecutive hours every 2 weeks from October to May for 2 years demonstrated increased global hand perfusion, reduced plasma adrenomedullin levels, and reduced frequency and severity of RP attacks. Frequency of RP declined from 23.2 per week at baseline to 13.2 per week after 2 weeks of treatment (43.1\% decline) and to 10.8 per week during the last 4 weeks of follow-up (53.4\% decline). RP severity scores declined approximately 40\%. Adrenomedullin is a potent vasodilator endothelial-derived peptide which levels increased in patients with systemic sclerosis. $\mathrm{N}$-acetylcysteine seemed to act as a vasodilator, perhaps via modulation of adrenomedullin levels..$^{95}$

\section{Statins}

The observed effects of the statins on endothelial function prompted assessment of statins in the therapy of RP associated with systemic sclerosis. One randomized study enrolled 84 patients with RP secondary to systemic sclerosis despite ongoing vasodilator therapy. Patients received atorvastatin $40 \mathrm{mg}$ per day (56 patients) or placebo (28 patients) for 4 months. The primary outcome was the number of digital ulcers, which declined from 3.3 at baseline to 2.4 at 4 months in the atorvastatin group compared with a reduction from 3.4 at baseline to 3 at 4 months in the placebo group $(P=0.001)$. Patients in the atorvastatin group had a mean of 1.6 new ulcers compared with 2.5 new ulcers per patient in the placebo group $(P=0.003)$. Patients in the atorvastatin group also demonstrated improvement in the Scleroderma Health Assessment Questionnaire Disability Index (SHAQ-DI; $P=0.001)$, VAS for RP severity $(P=0.005)$, VAS for digital ulcer severity $(P=0.001)$, and VAS pain scales $(P=0.004)$ compared with the placebo group. Endothelial markers of activation that improved from baseline in the statin group compared with the placebo group included IL-6, TNF-alpha, ET-1, nitric oxide, thrombomodulin, soluble E-selectin, von Willebrand factor, monocyte chemoattractant, fibrinogen, high sensitivity C-reactive protein, erythrocyte sedimentation rate, lipid peroxide, and malonylaldehyde. ${ }^{96}$

\section{Botulinum toxin-A}

Decreased pain and numbness, decreased frequency of vasospastic attacks, healing of digital ulcers, and increased blood flow was observed in three case series and a case report assessing interdigital injections of botulinum toxin in patients with primary and secondary RP. ${ }^{97-100}$ A dual mechanism of action has been suggested: inhibition of vasospasm by blocking cold-induced vasoconstriction and by preventing recruitment of alpha 2 receptors to vascular smooth muscle in cold conditions. ${ }^{98}$ Placebo-controlled studies are necessary to confirm the activity of botulinum toxin in RP.

\section{Conclusion}

In patients with primary RP, nonpharmacologic lifestyle modifications remain the first-line therapy. Calcium channel

Table 4 Newer therapies with demonstrated efficacy in Raynaud's phenomenon

\begin{tabular}{|c|c|c|c|c|}
\hline Agents & Class & Route & RP population & Effect \\
\hline MQX-503 & Nitrate & Topical & Primary and secondary & Reduced attack severity \\
\hline Iloprost & Prostaglandin analog & Intravenous & Secondary & $\begin{array}{l}\text { Reduced duration, frequency, and severity } \\
\text { of attacks; improved ulcer healing }\end{array}$ \\
\hline Bosentan & $\begin{array}{l}\text { Endothelin receptor } \\
\text { antagonist }\end{array}$ & Oral & Secondary & Reduced number of new digital ulcers \\
\hline Sildenafil & $\begin{array}{l}\text { Phosphodiesterase } \\
\text { type } 5 \text { inhibitor }\end{array}$ & Oral & Secondary & $\begin{array}{l}\text { Reduced duration, frequency, and severity } \\
\text { of attacks; improved ulcer healing }\end{array}$ \\
\hline Tadalafil & $\begin{array}{l}\text { Phosphodiesterase } \\
\text { type } 5 \text { inhibitor }\end{array}$ & Oral & Secondary & $\begin{array}{l}\text { Reduced duration, frequency, and severity } \\
\text { of attacks; improved ulcer healing }\end{array}$ \\
\hline
\end{tabular}


blockers or topical nitrates may be considered for those without an adequate response to lifestyle modification. Other therapies have not been demonstrated to be effective in this population.

In patients with secondary RP, lifestyle modifications should also be applied; however, pharmacologic management is more likely to be necessary. In addition to calcium channel blockers, there may be a role for topical nitrates, PDE5 inhibitors, endothelin antagonists, or prostaglandin derivatives (Table 4). Although additional clinical studies are necessary to validate the efficacy of these agents in RP, the clinical data, oral availability, and favorable tolerability profile suggests a trial of a PDE5 inhibitor may be appropriate in patients with severe symptoms associated with RP despite traditional vasodilator therapy. Further studies of statins, botulinum toxin, N-acetylcysteine are necessary to establish the role of these agents.

\section{Disclosure}

The author declares no conflicts of interest.

\section{References}

1. Wigley FM. Raynaud's phenomenon. $N$ Engl J Med. 2002;347: 1001-1008.

2. Cooke JP, Marshall JM. Mechanisms of Raynaud's disease. Vasc Med. 2005;10:293-307.

3. Bakst R, Merola JE, Franks AG Jr, Sanchez M. Raynaud's phenomenon: pathogenesis and management. J Am Acad Dermatol. 2008;59: 633-653.

4. Rosenkranz S, Diet F, Karasch T, Weibrauch J, Wassermann K, Erdmann E. Sildenafil improved pulmonary hypertension and peripheral blood flow in a patient with scleroderma-associated lung fibrosis and the Raynaud phenomenon [1etter]. Ann Intern Med. 2003;139:871-872.

5. Fries R, Shariat K, von Wilmowsky H, Bohm M. Sildenafil in the treatment of Raynaud's phenomenon resistant to vasodilatory therapy. Circulation. 2005;112:2980-2985.

6. Thompson AE, Pope JE. Calcium channel blockers for primary Raynaud's phenomenon: a meta-analysis. Rheumatology. 2005;44: $145-150$.

7. Thompson AE, Shea B, Welch V, Fenlon D, Pope JE. Calcium-channel blockers for Raynaud's phenomenon in systemic sclerosis. Arthritis Rheum. 2001;44:1841-1847.

8. Vinjar B, Stewart M. Oral vasodilators for primary Raynaud's phenomenon. Cochrane Database Syst Rev. 2008, Issue 2. Art. No.: CD006687. DOI: 10.1002/14651858.CD006687.

9. Dziadzio M, Denton CP, Smith R, et al. Losartan therapy for Raynaud's phenomenon and scleroderma. Arthritis Rheum. 1999;42:2646-2655.

10. Harding SE, Tingey PC, Pope J, et al. Prazosin for Raynaud's phenomenon in progressive systemic sclerosis. Cochrane Database Syst Rev. 1998, Issue 2. Art. No.: CD000956. DOI: 10.1002/14651858.CD000956.

11. ClinicalTrials.gov database. Accessed July 15, 2009.

12. Teh LS, Manning J, Moore T, Tully MP, O’Reilly D, Jayson MI. Sustained-release transdermal glyceryl trinitrate patches as a treatment for primary and secondary Raynaud's phenomenon. Br J Rheumatol. 1995;34:636-641.

13. Coppock JS, Hardman JM, Bacon PA, Woods KL, Kendall MJ. Objective relief of vasospasm by glyceryl trinitrate in secondary Raynaud's phenomenon. Postgrad Med J. 1986;62:15-18.

14. Franks AG Jr. Topical glyceryl trinitrate as adjunctive treatment in Raynaud's disease. Lancet. 1982;1(8263):76-77.
15. Hummers LK, Dugowson CE, Dechow FJ, Wise RA, Bartolucci A, Wigley FM. A multi-center, blinded, randomized, placebo-controlled study of MQX-503, a topical gel formulation of nitroglycerin, in patients with Raynaud phenomenon (RP) [abstract]. Arthritis Rheum. 2006; 54(9 Suppl):S523.

16. Chung L, Shapiro L, Fiorentino D, et al. MQX-503, a novel formulation of nitroglycerin, improves the severity of Raynaud's phenomenon. Arthritis Rheum. 2009;60:870-877.

17. Belch J, Fiorentino D, Denton C, et al. MQX-503, a novel topical nitroglycerin formulation, improves severity of symptoms associated with Raynaud's phenomenon [abstract]. Arthritis Rheum. 2008;58(9 Suppl):S622.

18. Rothfield N, Shapiro L, Fiorentino D, et al. Safety and tolerability of MQX-503, a novel investigational topical formulation of nitroglycerin for the treatment of Raynaud's phenomenon [abstract]. Arthritis Rheum. 2008;58(9 Suppl):S821.

19. Pope J, Fenlon D, Thompson A, et al. Iloprost and cisaprost for Raynaud's phenomenon in progressive systemic sclerosis. Cochrane Database Syst Rev. 1998; issue 2, Art. No.: CD000953. DOI: 10.1002/ 14651858.CD000953.

20. Wigley FM, Wise RA, Seibold JR, et al. Intravenous iloprost infusion in patients with Raynaud phenomenon secondary to systemic sclerosis. Ann Intern Med. 1994;120:199-206.

21. Yardumian DA, Isenberg DA, Rustin M, et al. Successful treatment of Raynaud's syndrome with iloprost, a chemically stable prostacycline analogue. Br J Rheumatol. 1988;27:220-226.

22. McHugh NJ, Csuka M, Watson H, et al. Infusion of iloprost, a prostacyclin analogue, for treatment of Raynaud's phenomenon in systemic sclerosis. Ann Rheum Dis. 1988;47:43-47.

23. Wigley FM, Seibold JR, Wise RA, McCloskey DA, Dole WP. Intravenous iloprost treatment of Raynaud's phenomenon and ischemic ulcers secondary to systemic sclerosis. J Rheumatol. 1992;19:1407-1414.

24. Kyle MV, Belcher G, Hazleman BL. Placebo controlled study showing therapeutic benefit of iloprost in the treatment of Raynaud's phenomenon. J Rheumatol. 1992;19:1403-1406.

25. Torley HI, Madhok R, Capell HA, et al. A double-blind, randomised, multicentre comparison of two doses of intravenous iloprost in the treatment of Raynaud's phenomenon secondary to connective tissue diseases. Ann Rheum Dis. 1991;50:800-804.

26. Kawald A, Burmester GR, Huscher D, Sunderkotter C, Riemerkasten G. Low versus high-dose iloprost therapy over 21 days in patients with secondary Raynaud's phenomenon and systemic sclerosis: a randomized, open, single-center study. J Rheumatol. 2008;35:1830-1837.

27. Rademaker M, Cooke ED, Almond NE, et al. Comparison of intravenous infusions of iloprost and oral nifedipine in treatment of Raynaud's phenomenon in patients with systemic sclerosis: a double-blind randomised study. BMJ. 1989;298:561-564.

28. Scorza R, Caronni M, Mascagni B, et al. Effects of long-term cyclic iloprost therapy in systemic sclerosis with Raynaud's phenomenon. A randomized, controlled study. Clin Exp Rheumatol. 2001;19:503-508.

29. Bettoni L, Geri A, Airo P, et al. Systemic sclerosis therapy with iloprost: a prospective observational study of 30 patients treated for a median of 3 years. Clin Rheumatol. 2002;21:244-250.

30. Hernandez FJG, Medina CO, Romero LM, et al. Iloprost for severe Raynaud's phenomenon and ischaemic ulcers related with systemic diseases. Med Clin (Barc). 2004:122:501-504.

31. Milio G, Corrado E, Genova C, et al. Iloprost treatment in patients with Raynaud's phenomenon secondary to systemic sclerosis and the quality of life: a new therapeutic protocol. Rheumatology. 2006:45:999-1004.

32. Lambova SN. Therapy with iloprost in patients with severe Raynaud's phenomenon secondary to scleroderma [abstract]. Ann Rheum Dis. 2006;65(Suppl 2):396.

33. Resende C, Castelao W, Fonseca JE, et al. Intravenous iloprost treatment of severe Raynaud's phenomenon secondary to connective tissue diseases [abstract]. EULAR 2002. Stockholm, Sweden, June 12-15, 2002: Abstract AB0227.

34. Zulian F, Corona F, Gerloni V, et al. Safety and efficacy of iloprost for the treatment of ischemic digits in pediatric connective tissue diseases [abstract]. EULAR 2002. Stockholm, Sweden, June 12-15, 2002: Abstract FR1025. 
35. Wigley FM, Korn JH, Csuka ME, et al. Oral iloprost treatment in patients with Raynaud's phenomenon secondary to systemic sclerosis. Arthritis Rheum. 1998;41:670-677.

36. Belch JJ, Capell HA, Cooke ED, et al. Oral iloprost as a treatment for Raynaud's syndrome: a double blind multicentre placebo controlled study. Ann Rheum Dis. 1995;54:197-200.

37. Black CM, Halkier-Sorensen L, Belch JJF, et al. Oral iloprost in Raynaud's phenomenon secondary to systemic sclerosis: a multicentre, placebo-controlled, dose-comparison study. Br J Rheumatol. 1998; 37:952-960.

38. Pakozdi A, Howell K, Wilson H, et al. Inhaled iloprost for the treatment of Raynaud's phenomenon. [abstract] American College of Rheumatology 2007 Annual Meeting. Boston, MA: November 6-11, 2007; abstract 1225.

39. Bartolone S, Trifiletti A, De Nuzzo G, et al. Efficacy evaluation of prostaglandin E1 against placebo in patients with progressive systemic sclerosis and significant Raynaud's phenomenon. Minerva Cardioangiol. 1999;47:137-143.

40. Mohrland JS, Porter JM, Smith EA, Belch J, Simms MH. A multiclinic, placebo-controlled, double-blind study of prostaglandin $\mathrm{E}_{1}$ in Raynaud's syndrome. Ann Rheum Dis. 1985;44:754-760.

41. Vayssairat M. Controlled multicenter double blind trial of an oral analog of prostacyclin in the treatment of primary Raynaud's phenomenon. J Rheumatol. 1996;23:1917-1920.

42. Korn JH, Mayes M, Cerinic MM, et al. Digital ulcers in systemic sclerosis: prevention by treatment with bosentan, an oral endothelin receptor antagonist. Arthritis Rheum. 2004;50:3985-3993.

43. Black C, Denton CP, Furst DE, et al. Bosentan reduces the number of new digital ulcers in patients with systemic sclerosis - open label extension to a double-blind trial [abstract]. Ann Rheum Dis. 2006; 65(Suppl 2):384.

44. Seibold JR, Denton CP, Furst DE, et al. Bosentan prevents occurrence but does not speed healing of digital ulcers in patients with systemic sclerosis (SSc) [abstract]. Annual Meeting of the American College of Rheumatology 2005; abstract L2.

45. Sfikakis PP, Papamichael C, Stamatelopoulos KS, et al. Improvement of vascular endothelial function using the oral endothelin receptor antagonist bosentan in patients with systemic sclerosis. Arthritis Rheum. 2007;56:1985-1993.

46. Tsifetaki N, Botzoris VG, Argyriou E, Drosos AA. Bosentan for digital ulcers in patients with systemic sclerosis. A prospective 3-year follow-up study [abstract]. American College of Rheumatology 2008 Annual Scientific Meeting; abstract 1785.

47. Garcia de la Pena-Lefebvre P, Rubio SR, Exposito MV, et al. Long-term experience of bosentan for treating ulcers and healed ulcers in systemic sclerosis patients. Rheumatology. 2008;47:464-466.

48. Launay D, Diot E, Pasquier E, et al. Bosentann for treatment of active digital ulcers in patients with systemic sclerosis (9 cases). Presse Med. 2006;35:587-592.

49. Selenko-Gebauer N, Duschek N, Minimair G, Stingl G, Karlhofer F. Successful treatment of patients with severe secondary Raynaud's phenomenon with the endothelial receptor antagonist bosentan. Rheumatology. 2006;45:iii45-iii48.

50. Funauchi M, Kishimoto K, Shimazu H, et al. Effects of bosentan on the skin lesions: an observational study from a single center in Japan. Rheumatol Int. 2009;29:769-775.

51. Hettema ME, Zhang D, Bootsma H, Kallenberg CGM. Bosentan therapy for patients with severe Raynaud's phenomenon in systemic sclerosis [letter]. Ann Rheum Dis. 2007;66:1398-1399.

52. Ramos-Casals M, Brito-Zeron P, Nardi N, et al. Successful treatment of severe Raynaud's phenomenon with bosentan in four patients with systemic sclerosis [letter]. Rheumatology. 2004;43:1454-1456.

53. Dunne J, Dutz J, Shojania K, Ng B, van Elden S. Treatment of severe Raynaud's phenomenon with bosentan in a patient with systemic sclerosis [letter]. Rheumatology. 2006;45:911-912.

54. Moore TL, Vail A, Herrick AL. Assessment of digital vascular structure and function in response to bosentan in patients with systemic sclerosis-related Raynaud's phenomenon [letter]. Rheumatology. 2007;46:363-364.
55. Halcox JPJ, Nour KRA, Zalos G, et al. The effect of sildenafil on human vascular function, platelet activation, and myocardial ischemia. $J \mathrm{Am}$ Coll Cardiol. 2002;40:1232-1240.

56. Watanabe H, Nishio S, Ohmae E, et al. Sildenafil improves forearm blood flow in patients with Raynauds phenomenon [abstract]. Eur Heart J. 2004;25(Suppl.):202.

57. Carlino G. Treatment of Raynaud's phenomenon with tadalafil, a phosphodiesterase-5 inhibitor [abstract]. Ann Rheum Dis 2005;64 (Suppl 3):258.

58. Zamiri B, Koman AL, Smith BP, et al. Double-blind, placebo-controlled trial of sildenafil for the management of primary Raynaud's phenomenon [abstract]. Ann Rheum Dis. 2004;63(Suppl. 1):484-485.

59. ShenoyP, Agarwal V, Kumar S, et al. Efficacy of tadalafil in secondary Raynaud's phenomenon resistant to vasodilator therapy: a doubleblind randomized cross-over trial [abstract]. Arthritis Rheum. 2008; 58(9 Suppl):S402

60. Schiopu E, Hsu VM, Impens AJ, Rothman JA, McCloskey DA, Wilson JE, et al. Randomized placbo-controlled crossover trial of tadalafil in Raynaud's phenomenon secondary to systemic sclerosis. $J$ Rheumatol. 2009;36:2264-2268.

61. Pakozdi A, Howell K, Black CM, Denton CP. Addition of the short term phosphodiesterase-5 inhibitor sildenafil to iloprost therapy for scleroderma digital vasculopathy [abstract]. ACR/ARHP Scientific Meeting 2007. Boston, MA: November 6-11, 2007; abstract 2167.

62. Abeles M, Abeles AM. Phosphodiesterase inhibitor tadalafil in the treatment of ischemic digital ulcers/digital necrosis due to sclerodermaassociated Raynaud's phenomenon [abstract]. Arthritis Rheum. 2008; 58(9 Suppl):S822

63. Caglayan E, Huntgeburth M, Karasch T, et al. Phosphodiesterase type 5 inhibition is a novel therapeutic option in Raynaud disease. Arch Intern Med. 2006;166:231-233.

64. Kumar N, Griffiths B, Allen J. Thermographic and symptomatic effect of a single dose of sildenafil citrate on Raynaud's phenomenon in patients with systemic sclerosis: a potential treatment [letter]. J Rheumatol. 2006;33(9):1918-1919.

65. Becker M, Bruckner CS, Scherer H, Burmester GR, Riemekasten G. Effect of sildenafil on digital ulcers in systemic sclerosis - analysis from a single centre study [abstract]. Ann Rheum Dis. 2009;68(Suppl 3):96.

66. Brueckner C, Scherer U, Burmester G, Becker MO, Dragun D, Riemekasten G. Effect of sildenafil on healing of digital ulcers in patients with systemic sclerosis [abstract]. Ann Rheum Dis. 2008; 67(Suppl 2):362.

67. Gore J, Silver R. Oral sildenafil for the treatment of Raynaud's phenomenon and digital ulcers secondary to systemic sclerosis. Ann Rheum Dis. 2005;64:1387.

68. Baak SW. Treatment of Raynaud's phenomena with the PDE-5 inhibitor, Cialis (tadalafil) in patients with scleroderma and lupus [abstract]. Arthritis Rheum. 2005;52(9 Suppl.):S169.

69. Lichtenstein JR. Use of sildenafil citrate in Raynaud's phenomenon: comment on the article by Thompson et al. [letter] Arthritis Rheum. 2003;48:282-283.

70. Cheung GTY, Lau CS, Kumana CR. Phosphodiesterase-5 inhibitors relieve symptoms of severe Raynaud's phenomenon [abstract]. Ann Rheum Dis. 2004;63(Suppl 1):313.

71. Kumana CR, Cheung GTY, Lau CS. Severe digital ischaemia treated with phosphodiesterase inhibitors. Ann Rheum Dis. 2004;63:1522-1524.

72. Colglazier CL, Sutej PG, O'Rourke KS. Severe refractory fingertip ulcerations in a patient with scleroderma: successful treatment with sildenafil. $J$ Rheumatol. 2005;32:2440-2442.

73. Baumhaekel M, Scheffler P, Boehm M. Use of tadalafil in a patient with a secondary Raynaud's phenomenon not responding to sildenafil. Microvascular Res. 2005;69:178-179.

74. Kropman RF. Raynaud's phenomenon of the penis. J Urol. 2004;171:1630.

75. Kamata Y, Kamimura T, Iwamoto M, Minota S. Comparable effects of sildenafil citrate and alprostadil on severe Raynaud's phenomenon in a patient with systemic sclerosis. Clin Exp Dermatol. 2005;30:451. 
76. Yung A, Reay N, Goodfield MD. Improvement in digital flexibility and dexterity following ingestion of sildenafil citrate (Viagra) in limited systemic sclerosis. Arch Dermatol. 2005;141:831-833.

77. Sandorfi N, Jimenez SA. Treatment of digital ulceration due to Raynaud's phenomenon (RP) with long acting phosphodiesterase 5 (PDE5) inhibitor: tadalafil [abstract]. Ann Rheum Dis. 2007;66(Suppl 2): 223-224.

78. Friedrichson E, Rehberger P, Fuhrmann JT, Walz F, Meurer M, Pfeiffer C. Fast and efficient healing of scleroderma-associated acral ulcers with sildenafil. Hautarzt. 2008;59:230-232.

79. Lal A, Fernando CE. Efficacy of vardenafil in a patient with digital gangrene due to severe Raynaud's [abstract]. ACR/ARHP Scientific Meeting 2007. Boston, MA: November 6-11, 2007; Abstract CRC04.

80. Della Rossa A, Doveri M, D’Ascanio A, et al. Oral sildenafil in skin ulcers secondary to systemic sclerosis [abstract]. Ann Rheum Dis. 2009; 68(Suppl 3):268.

81. Friedman EA, Harris PA, Wood AJJ, Stein CM, Kurnik D. The effects of tadalafil on cold-induced vasoconstriction in patients with Raynaud's phenomenon. Clin Pharmacol Ther. 2007;81:503-509.

82. Bolte MA, Avery D. Case of fluoxetine-induced remission of Raynaud's phenomenon - a case report. Angiology. 1993;44:161-163.

83. Rey J, Cretel E, Jean R, Pastor MJ, Durand JM. Serotonin reuptake inhibitors, Raynaud's phenomenon and erythromelalgia. Rheumatology. 2003;42:601-602.

84. Buecking A, Rougemont E, Zullino DF. Treatment of Raynaud's phenomenon with escitalopram. Int J Neuropsychopharmacol. 2005; 8:307-308.

85. Coleiro B, Marshall SE. Treatment of Raynaud's phenomenon with the selective serotonin reuptake inhibitor fluoxetine. Rheumatology. 2001;40:1038-1043

86. Bell C, Coupland N, Creamer P. Digital infarction in a patient with Raynaud's phenomenon associated with treatment with a specific serotonin reuptake inhibitor. A case report. Angiology. 1996;47: 901-903.

87. Peiró AM, Margarit C, Torra M. Citalopram-induced Raynaud's phenomenon. Rheumatol Int. 2007;27:599-601.

88. Bertoli R, Girardin F, Russmann S, Lauterburg BH. Raynaud's phenomenon induced by drugs acting on neurotransmission: two cases under reboxetine and one under tegaserod. Eur J Clin Pharmacol. 2003;58:717
89. Rudnick A, Modai I, Zelikovski A. Fluoxetine-induced Raynaud's phenomenon. Biol Psychiatry. 1997;41:1218-1221.

90. De Broucker T, Lhote F. Severe Raynaud's phenomenon associated with interferon-beta $1 \mathrm{a}$ and fluoxetine. Ann Med Interne (Paris). 2000;151:424-425.

91. Kato S, Kishiro I, Machida M, Fuse D, Yoshida T, Kaneko N Suppressive effect of sarpogrelate hydrochloride on respiratory failure and right ventricular failure with pulmonary hypertension in patients with systemic sclerosis. J Int Med Res. 2000;28:258-268.

92. Kumagai S, Morinobu A, Ozaki S, Nakao K, Ishida H. Sarpogelate hydrochloride for Raynaud's phenomenon of patients with collagen diseases. Ryumachi. 1998;38:504-510.

93. Ogawa T, Ogura T, Izumi Y, et al. Sarpogelate hydrochloride therapy for Raynaud's phenomenon in patients with systemic sclerosis [abstract]. Arthritis Rheum. 2008;58(9 Suppl):s821-s822.

94. Sambo P, Amico D, Giacomelli R, et al. Intravenous N-acetylcysteine for treatment of Raynaud's phenomenon secondary to systemic sclerosis: a pilot study. J Rheumatol. 2001;28:2257-2262.

95. Salsano F, Letizia C, Proietti M, et al. Significant changes of peripheral perfusion and plasma adrenomedullin levels in $\mathrm{N}$-acetylcysteine long term treatment of patients with sclerodermic Raynaud's phenomenon. Int J Immunopathol Pharmacol. 2005;18:761-770.

96. Abou-Raya A, Abou-Raya S, Helmii M. Statins: potentially useful in therapy of systemic sclerosis-related Raynaud's phenomenon and digital ulcers. J Rheumatol. 2008;35:1801-1808.

97. Sycha T, Graninger M, Auff E, Schnider P. Botulinum toxin in the treatment of Raynaud's phenomenon: a pilot study. Eur J Clin Invest. 2004;34:312-313.

98. Van Beek AL, Lim PK, Gear AJL, Prizker MR. Management of vasospastic disorders with botulinum toxin A. Plast Reconstr Surg. 2007;119:217-226.

99. Fregene A, Ditmars D, Siddiqui A. Botulinum toxin type A: a treatment option for digital ischemia in patients with Raynaud's phenomenon. $J$ Hand Surg. 2009;34A:446-452.

100. Kossintseva I, Barankin B. Improvement in both Raynaud disease and hyperhidrosis in response to botulinum toxin type A treatment J Cutaneous Med Surg. 2008;12:189-193.
Vascular Health and Risk Management

\section{Publish your work in this journal}

Vascular Health and Risk Management is an international, peerreviewed journal of therapeutics and risk management, focusing on concise rapid reporting of clinical studies on the processes involved in the maintenance of vascular health; the monitoring, prevention and treatment of vascular disease and its sequelae; and the involvement of

\section{Dovepress}

metabolic disorders, particularly diabetes. This journal is indexed on PubMed Central and MedLine. The manuscript management system is completely online and includes a very quick and fair peer-review system, which is all easy to use. Visit http://www.dovepress.com/ testimonials.php to read real quotes from published authors 